\title{
A Study of the Impact of Social Media Characteristics on Customer Adoption Intention of Social Media
}

\author{
Yongbing Jiao, Jian Yang, Shanling Xu \\ School of Economics and Management \\ Ningbo University of Technology \\ Ningbo, China \\ robynjoy@outlook.com
}

\begin{abstract}
Recent research on the factors affecting customer adoption of social media has been conducted by many scholars, but no research can be found to be carried out from the perspective of social media characteristics. The purpose of this study is to fill this void. Our conceptual framework incorporates customer adoption intention as endogenous variable and social media characteristics (information openness, participation, interaction, sharing, and connectedness) as exogenous variables. According to the 624 samples surveyed online, we had a data analysis by running the software of AMOS 7.0 and SPSS 17.0. Our findings demonstrated that information openness, participation, interaction, sharing and connectedness positively affect customer adoption intention.
\end{abstract}

Keywords- social media; social media characteristics; adoption intention

\section{INTRODUCTION}

The usage of social media has been increased very quickly in recent years and the marketing application of social media is being spread and popularized most extensively with the active participation of various firms both in China and abroad. Social media has become a newly marketing tool for firms to maintain the existing customers as well as to capture the new ones. Customers can create ideas, adjust contents, share opinions and discuss topics through social media.

Social media is a concept emerging in recent years. It is a newly online interactive media granting users extremely participating space. The types of social media includes bloggers, wikis, podcasts, tribunes, social networks, instant messengers, and content communities, etc. Social media changes the one-to-many communicating means into the manyto-many interacting mode. And so social media has the characteristics of information openness, participation, interaction, sharing and connectedness, etc.

Companies can provide products and services for their customers with the help of social media, thus bringing about social media marketing. In contrast with traditional marketing, social marketing can reach anybody and every company that are online in any place of the world. Thus, social media marketing has completely been adopted by many companies in order to gain more customer shares. However, there still exist a lot of companies that cannot link their customers by using social media. One of the important reasons is that these companies cannot identity and judge what on earth factors will impact customers adopting social media.

Researchers conducted the study of factors affecting customer adoption of social media from different perspectives: some from the perspective of Technology Acceptance Model, others from the perspective of Social Capital, and still others from the perspective of Uses and Gratifications Theory. However, few researchers conducted the study of factors affecting customer adoption of social media from the perspective of social media characteristics. The purpose of our study is to fill this void. We build the conceptual framework by incorporating customer adoption intention as endogenous variable and social media characteristics as exogenous variables. We find that information openness, participation, interaction, sharing and connectedness positively affect customer adoption intention.

The rest of our study is organized as follows. The second section relates to a literature review about social media and its adoption influencing factors. The third section presents our research model and hypotheses. The fourth section discusses our research methodology. The fifth section describes the data analysis of our investigation. The sixth section introduces the conclusions of our investigation, outlining the implications of the findings, the limitations and the future research directions of the study.

\section{LITERATURE REVIEW}

Social media is a newly online interactive media that grants extremely participating space to users. Social media changes the one-to-many communicating means into the many-to-many interacting mode. Social media has the characteristics of information openness, participation, interaction, sharing and connectedness, and so on [1] [2] [3] [4]. It is very difficult to give an accurate definition of social media though it is changing the communication means of people as well as of organizations [5].
ACKNOWLEDGMENT: (i) This study is funded by the Humanities and Social Sciences Fund of Ministry of Education (grant \#, 13YJA630038), China. (ii) This study is funded by the Special Program of the Academic Discipline of Humanities and Social Sciences Rehabilitation Foundation, Ningbo University of Technology, China. (iii) The author gratefully acknowledges the support of K. C. Wong Education Foundation. 
Social media is a very popular phrase emerging in recent years, which is often the substitute of another fashionable phrase, Web 2.0. O'Reilly formally created the phrase Web 2.0 and describes it as a newly cooperative network based on internet that can utilize the collective wisdom [3]. Hoegg et al. define Web 2.0 as the philosophy mutually maximizing the collective wisdom, in which every participant can increase its value by format and dynamic information sharing and creation [6]. Kietzmann et al. articulates that social media is a socially interactive media and a superset surpassing social communication [7]. The accessibility and measurability anywhere of communication skills completely enable social media to essentially change the communication means between organizations, communities and persons [7]. Dykeman argues that social media can enable people to have the following activities: publishing digitally creative contents, providing and acquiring real-time feedbacks by online discussion and review, adjusting and correcting digital content [8]. According to the definition of Strauss \& Frost, social media is a network tool and platform, where users can jointly investigate network content, share their opinions and experiences, and build up relations for commercial activities or amusement activities [9]. Safko \& Brake define social media as activity, practice and behavior between human groups who share information, knowledge and opinion online by using interactive media [4]. Interactive media are tools based upon internet, through which people can create and easily communicate the information in the form of words, pictures, and videos, and thus people will melt into social media ecology circles [4]. Constantinides \& Fountain define Web 2.0 as a set of open source, interaction and online application controlled by users [1]. Online application controlled by users includes users' experience, users' knowledge, and market forces regarding users as business customers and social process participants [1]. Web 2.0 applications support the establishment of informal users' network, promoting the flow of ideas and knowledge by generating, absorbing, sharing, compiling and refining the information content effectively and efficiently [1]. Kaplan \& Haenlein define social media as an internet-based application which is built upon the bases of web2.0 conception and technology, permitting users to create and exchange their generated contents [2].

Social media has had a great impact on marketing practice. A lot of companies have been busy integrating various social media applications into their marketing strategies. However, there still exist many companies that cannot develop their customer relationship marketing strategies through social media. One of the main reasons is that these companies cannot identity and judge what on earth factors will impact customers adopting social media.

Researchers conducted the study of factors affecting customer adoption of social media from different perspectives. Nasri \& Charfeddine did an exploration of customer Adoption of social media by using Technology Acceptance Model and Theory of Reasoned Action [10]. Raacke \& Bonds-Raacke investigated customer adoption of social media by applying the Uses and Gratifications Theory [11]. Rahman et al. examined their study on customer adoption of social media from the perspective of privacy and trust [12]. Steinfield et al. conducted their research on customer adoption of social media from the

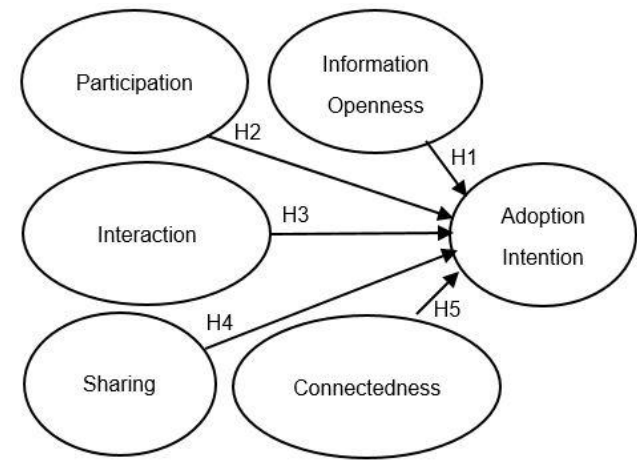

Figure 1. The research model

viewpoint of Social Capital [13]. However, no study on factors affecting customer adoption of social media can be found from the perspective of social media characteristics. And so our study is to fill this void.

\section{RESEARCH MODEL AND HYPOTHESES}

In accordance with the existing literature, we constructed the research model. As is shown in figure 1, our conceptual framework is built by incorporating customer adoption intention as endogenous variable and social media characteristics (information openness, participation, interaction, sharing, and connectedness) as exogenous variables.

\section{A. The impact of Information Openness on Adoption Intention $(I O \rightarrow A I)$}

Information openness refers to the degree to which information in social media is opened to the public [1] [4]. When purchasing products and services in social media, customers often evaluation the products and services in the light of the information provided by the related companies and other customers. The more information they can get from the social media, the more adoption intention of social media customers will have. And so we can infer as follows:

H1: Information openness has a positive impact on customer adoption intention of social media.

\section{B. The impact of Participation on Adoption Intention $(P \rightarrow A I)$}

Participation refers to the extent to which customers involve themselves into the service production and delivery in the psychic and physical aspects [14] during the course of using social media. Rodi \& Kleine argue that one important motivation of customer participation belongs to psychic aspect, i.e., customers can gain perception of enjoyment, novelty and playfulness through their participating activities [15]. Some customers may actively take part in the service production and delivery due to the psychic reward [16]. Participation is one of the main characteristics of social media. Social media can arouse the participating enthusiasm of customers, leading to much more adoption intention. Thus we can infer as follows:

H2: Participation has a positive impact on customer adoption intention of social media.

\section{The impact of Interaction on Adoption Intention $(I \rightarrow A I)$}

Interaction refers to direct communication and involvement between users and system interface [17], the aim of interaction 
is to make the social media much more customized. We argue that in social media, interaction exists not only in the communication and involvement between customers and social media but also in the discussion and dialogue between employees and customers as well as between customers and customers. The communication and dialogue in social media is multi-directional and interactive, which can excite customers' much more intention to adopt social media. Therefore we can give the following inference:

H3: Interaction has a positive impact on customer adoption intention of social media.

\section{The impact of Sharing on Adoption Intention $(S \rightarrow A I)$}

Sharing refers to the mutual delivery and acquirement of information, idea, value, experience, reviews about products and services among users when using social media [1] [2] [3]. Sharing can increase the customers' positive feelings such as perception of novelty and playfulness [15]. The customers in social media often constitute various communities according to their common topics and values. Community members in social media can exchange ideas, opinions, product information, experiences, etc. among themselves, thus arouse their more intention to adopt social media. Therefore we can infer as follows:

H4: Sharing has a positive impact on customer adoption intention of social media.

\section{E. The impact of Connectedness on Adoption Intention $(C \rightarrow A I)$}

In social media, users are accustomed to merging all kinds of contents by linking to various social networking sites [1] [2]. Users can find information, ideas, friends with common interests, communities, and cooperative partners much more easily and quickly than ever [4]. The characteristics of connectedness can provide customers with effective solutions to their concerned problems, which can surely increase their adoption intention of social media. And so we can draw the following inference:

H5: Connectedness has a positive impact on customer adoption intention of social media.

\section{RESEARCH METHODOLOGY}

We designed our study into two steps, the first step dealt with operational variable measurement and questionnaire design, and the second step dealt with data collection and sample characteristics.

\section{A. Operational Variable Measurement and Questionnaire Design}

The questionnaire was designed in the light of Likert 7point Scale, which ranged from "Strongly Disagree" to "Strongly Agree". Some questions were from the existing studies which had been proved to have good validity and reliability, other questions were compiled by ourselves according to the definitions of the existing literature. The scale of information openness was developed from the research of Constantinides \& Fountain [1]. And the scale of participation was designed in accordance with the study of Dabholkar [16]. The interaction scale was designed on the basis of Palmer's research [17], the scale of sharing was developed in accordance with the research of Rodi \& Kleine [15], and the scale of connectedness was developed from the research of Safko \& Brake [4].

\section{B. Data Collection and Sample Characteristics}

In order to analyze accurately and effectively the factors impacting customer adoption intention of social media, we locked our sample scope into the customers who had already adopted social media. Data were collected by means of online investigation conducted in Ningbo, China from March to May, 2013. The respondents were mainly concentrated on the university students, white collars in companies, public servants, staff in hospitals, staff in educational organizations, and scientific researchers. The investigation were mainly conducted by social media tools or platforms such as blogs, podcasts, instant messengers, content communities, tribunals, and social networking sires. Altogether 1000 questionnaires were sent and 650 ones were collected, thus the collection rate is $65 \%$. Then according to consistency test, 26 invalid questionnaires were deleted, and so the valid ones are 624 , the response rate is $62.4 \%$. TABLE I demonstrates the information of the valid questionnaires' characteristics.

TABLE I. QUESTIONNAIRE CHARACTERISTIC INFORMATION

\begin{tabular}{|c|c|c|c|}
\hline \multicolumn{2}{|c|}{ Index } & \multirow{2}{*}{$\begin{array}{c}\begin{array}{c}\text { Number of } \\
\text { People }\end{array} \\
335\end{array}$} & \multirow{2}{*}{$\begin{array}{c}\begin{array}{c}\text { percenta } \\
\text { ge }\end{array} \\
53.7\end{array}$} \\
\hline & Male & & \\
\hline Gender & Female & 289 & 46.3 \\
\hline \multirow{4}{*}{ Age } & $18-25$ years old & 182 & 29.2 \\
\hline & 26-35 years old & 161 & 25.8 \\
\hline & $36-45$ years old & 136 & 21.8 \\
\hline & $\geq 46$ years old & 145 & 23.2 \\
\hline \multirow{2}{*}{ Marital status } & Married & 303 & 48.6 \\
\hline & Single & 321 & 51.4 \\
\hline \multirow{4}{*}{ Occupation } & University student & 149 & 23.9 \\
\hline & White Collar & 165 & 26.4 \\
\hline & Public servant & 105 & 16.8 \\
\hline & $\begin{array}{c}\text { Medical, education } \\
\text { and research Institutes }\end{array}$ & 205 & 32.9 \\
\hline \multirow{5}{*}{$\begin{array}{l}\text { Monthly } \\
\text { income }\end{array}$} & $\leq 2000 \mathrm{RMB}$ & 85 & 13.6 \\
\hline & 2001-3500 RMB & 155 & 24.8 \\
\hline & 3501-5000 RMB & 185 & 29.6 \\
\hline & 5001-7000 RMB & 135 & 21.6 \\
\hline & $\geq 7000 \mathrm{RMB}$ & 74 & 11.9 \\
\hline \multirow{4}{*}{$\begin{array}{l}\text { Educational } \\
\text { background }\end{array}$} & $\leq$ Middle school & 113 & 18.1 \\
\hline & Junior college & 169 & 27.1 \\
\hline & Undergraduate & 182 & 29.2 \\
\hline & Postgraduate & 160 & 25.6 \\
\hline \multirow{7}{*}{$\begin{array}{l}\text { Social media } \\
\text { type }\end{array}$} & $\mathrm{B} \log \mathrm{s}$ & 451 & 72.3 \\
\hline & Wikis & 257 & 41.2 \\
\hline & Tribunals & 329 & 52.7 \\
\hline & $\begin{array}{l}\begin{array}{l}\text { Social networking } \\
\text { sites }\end{array} \\
\end{array}$ & 542 & 86.9 \\
\hline & Podcasts & 233 & 37.3 \\
\hline & Instant messengers & 510 & 81.7 \\
\hline & Content Communities & 476 & 76.3 \\
\hline
\end{tabular}


TABLE II. MEASUREMENT MODEL TEST

\begin{tabular}{|c|c|c|c|c|c|c|c|c|c|}
\hline Variable & Item Index & GFI & AGFI & RMR & RMSEA & CFI & Cronbach's $\alpha$ & FL & SMC \\
\hline \multirow{3}{*}{ AI } & AI1 & \multirow{3}{*}{.929} & \multirow{3}{*}{.938} & \multirow{3}{*}{.021} & \multirow{3}{*}{.007} & \multirow{3}{*}{.943} & \multirow{3}{*}{.81} & .724 & .726 \\
\hline & AI2 & & & & & & & .634 & .537 \\
\hline & $\mathrm{AI} 3$ & & & & & & & .652 & .619 \\
\hline \multirow{3}{*}{ IO } & IO1 & \multirow{3}{*}{.947} & \multirow{3}{*}{.921} & \multirow{3}{*}{.016} & \multirow{3}{*}{.003} & \multirow{3}{*}{.954} & \multirow{3}{*}{.84} & .731 & .720 \\
\hline & IO2 & & & & & & & .829 & .697 \\
\hline & IO3 & & & & & & & .835 & .668 \\
\hline \multirow{4}{*}{$\mathbf{P}$} & P1 & \multirow{4}{*}{.956} & \multirow{4}{*}{.921} & \multirow{4}{*}{.019} & \multirow{4}{*}{.005} & \multirow{4}{*}{.978} & \multirow{4}{*}{.88} & .931 & .610 \\
\hline & P2 & & & & & & & .887 & .594 \\
\hline & P3 & & & & & & & .557 & .575 \\
\hline & P4 & & & & & & & .677 & .667 \\
\hline \multirow{4}{*}{ I } & I1 & \multirow{4}{*}{.947} & \multirow{4}{*}{.982} & \multirow{4}{*}{.014} & \multirow{4}{*}{.002} & \multirow{4}{*}{.988} & \multirow{4}{*}{.86} & .744 & .831 \\
\hline & I2 & & & & & & & .556 & .585 \\
\hline & I3 & & & & & & & .627 & .764 \\
\hline & $\mathrm{I} 4$ & & & & & & & .763 & .649 \\
\hline \multirow{4}{*}{$\mathbf{S}$} & S1 & \multirow{4}{*}{.925} & \multirow{4}{*}{.866} & \multirow{4}{*}{.003} & \multirow{4}{*}{.001} & & & .787 & .835 \\
\hline & S2 & & & & & 897 & 05 & .822 & .752 \\
\hline & S3 & & & & & ו וס. & 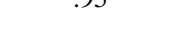 & .779 & .657 \\
\hline & S4 & & & & & & & .687 & .582 \\
\hline & $\mathrm{C} 1$ & & & & & & & .756 & .821 \\
\hline C & $\mathrm{C} 2$ & 967 & 964 & .008 & .004 & .928 & .95 & .873 & .705 \\
\hline & C3 & & & & & & & .722 & .627 \\
\hline
\end{tabular}

Notes: Factor Loading is significant at $\mathrm{p}=0.001$ level. $\mathrm{AI}=$ Adoption Intention, $\mathrm{IO}=$ Information Openness, $\mathrm{P}=\mathrm{Participation}, \mathrm{I}=\mathrm{Interaction}, \mathrm{S}=\mathrm{Sharing}$, $\mathrm{C}=$ Connectedness

We can find the information of the characteristics of the respondents investigated in our research, as is demonstrated in TABLE I. With regard to the gender, the male is about $53.7 \%$, and the female is about $46.3 \%$. As far as the age is concerned, the persons from 18 to 45 years of age occupy $76.8 \%$. As for the marital status, the respondents who are married occupy $48.6 \%$ and those who are single occupy $51.4 \%$. So far as the occupation is concerned, the respondents who are university students occupy $23.9 \%$, and those from white collars in companies, from public services, from hospitals, and from the educational and research departments are $76.1 \%$. With regard to monthly income, the respondents whose monthly income are between 2001 and 7000RMB occupy $76 \%$. As to educational background, the persons who have the junior college level or above are $81.9 \%$. As far as the social media type is concerned, the users of blogs, wikis, tribunals, social networking sites, podcasts, instant messengers, and content communities are $72.3 \%, 41.2 \%, 52.7 \%, 86.9 \%, 37.3 \%, 81.7 \%$, and $76.3 \%$ separately.

\section{DATA ANALYSIS}

We firstly conducted the measurement model test and then did the structural model test when having the data analysis of this research.

\section{A. Measurement Model Test}

Running the software of AMOS 7.0 and SPSS 17.0, we conducted the reliability and validity test of measurement model. As is illustrated in TABLE II, the Cronbach's a values in all the variables are above or equal to 0.80 , the Squared Multiple Correlations (SMC) values in all the items of their correspondent variables are above or equal to 0.50 , meaning all the variables have a higher internal consistency reliability. The
Standard Factor Loading (FL) values in all the items of their correspondent variables are over 0.50 or 0.70 under the condition of significance level at $\mathrm{p}=0.001$, which suggests that all the variables have a good validity. The values of Goodness of Fit Index (GFI), Adjust Goodness of Fit Index (AGFI), and Comparative Fit Index (CFI) of all the variables are close to or above 0.90, the values of Root Means square Residual (RMR) and the values of Root Mean Square Error of Approximation (RMSEA) of all the variables are below 0.05 , so all the variables are verified to have a satisfying reliability, validity and goodness of fit.

\section{B. Structural Model Test}

We can see the statistics of the structural model test which is demonstrated in TABLE III and figure 2.

As is demonstrated in TABLE III, the value of Ratio chisquare with Degrees of Freedom (CMIN/DF) is 2.479 (the standard value should be between 2.0 and 5.0), the values of Goodness of Fit Index (GFI), Adjust Goodness of Fit Index (AGFI), Comparative Fit Index (CFI), Normed Fit Index (NFI) and Incremental Fit Index (IFI) are all above 0.90, the value of Root Means square Residual (RMR) is below 1.0, and the value of Root Mean Square Error of Approximation (RMSEA) is below 0.05 . Therefore, it is verified that the overall structural model has a satisfying perfect goodness of fit.

TABLE III. STRUCTURAL MODEL TEST

\begin{tabular}{|c|c|c|c|c|}
\hline Index & CMIN/DF & GFI & AGFI & CFI \\
\hline Result & 2.237 & .912 & .911 & .925 \\
\hline Index & NFI & IFI & RMR & RMSEA \\
\hline Result & .921 & .908 & .106 & .009 \\
\hline
\end{tabular}




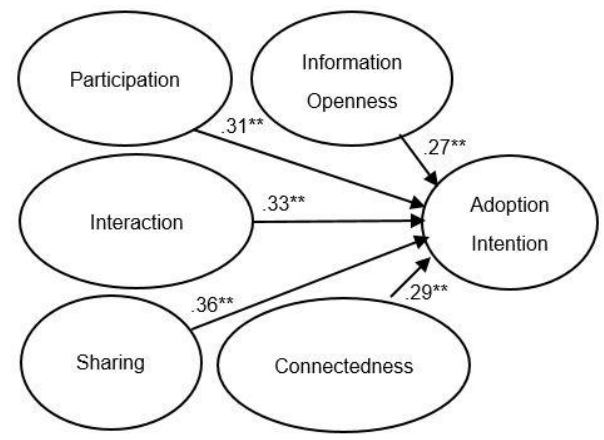

Figure 2. The standard road coefficient of the model

We can evaluate whether or not the hypotheses are acceptable, judging by the standard road coefficient of the structural equation model. As is demonstrated in fig. 2 , under the condition of significance level at $\rho \leq 0.001$ : the standard road coefficient of hypothesis $1(\mathrm{IO} \rightarrow \mathrm{AI})$ is 0.27 , meaning hypothesis 1 is acceptable; the standard road coefficient of hypothesis $2(\mathrm{P} \rightarrow \mathrm{AI})$ is 0.31 , meaning hypothesis 2 is acceptable; the standard road coefficient of hypothesis $3(\mathrm{I} \rightarrow \mathrm{AI})$ is 0.33 , meaning hypothesis 3 is acceptable; the standard road coefficient of hypothesis $4(\mathrm{~S} \rightarrow \mathrm{AI})$ is 0.36 , meaning hypothesis 4 is acceptable; and the standard road coefficient of hypothesis $5(\mathrm{C} \rightarrow \mathrm{AI})$ is 0.29 , meaning hypothesis 5 is also acceptable.

\section{CONCLUSIONS}

Our purpose is to construct a research model and to test the impact of social media characteristics on customer adoption intention. Our research model demonstrated adequate fit with the data; all the causal relationships in the model were found to be significant. We can draw the following managerial implications. First, since information openness is a very important factor impacting customer adoption intention of social media, companies should do their utmost to provide the most detailed information for their customers. Second, as participation can raise customer adoption intention of social media, companies should make the related social media more attractive and appealing so as to allure more customers into their related social media. Third, companies have to design their social media more interactive in order to excite customers to be more active to adopt social media. Fourth, companies must ensure and encourage all the members adopting social media to share ideas, information, experience, values, and so on together in order to retain the existing customers as well as acquire the new ones. Last but far from the least, connectedness plays an important role in customer adoption intention of social media, and so companies should allow and encourage as many as links to their social media so as to attract more customers to participate in the social media.

Our contribution in this research is to testify the impact of social media characteristics on customer adoption intention of social media. However, there exist limitations in this research and we hope we can break through these limitations in future directions. First, the characteristics selected in this study may not cover all the characteristics of social media. Other characteristics such as creation, cooperation, and reciprocity, etc. may also impact customer adoption intention. Therefore future research can consider incorporating other social media characteristics into the research model. Second, we only limit the samples in our study to the customers in China, but there are many other social media customers in many other countries. Future research can extend the samples from China to other countries. Meanwhile, future research can also do a comparative cross-cultural investigation according to the samples from China and another country so that we can discover culture-related factors influencing customer adoption intention of social media.

\section{REFERENCES}

[1] E Constantinides, \& S. Fountain, "Web 2.0: Conceptual Foundations and Marketing Issues," Journal of Direct, Data and Digital Marketing Practice, Vol. 9, 2008, pp. 231-244.

[2] A. M Kaplan, \& M. Haenlein, "Users of the world, unite! The challenges and opportunities of Social Media," Business Horizons, Vol. 53, 2010, pp. 59-68.

[3] T. O'Reilly, "What is Web 2.0? Design Patterns and Business Models for the Next Generation of Software," http://www.oreillynet.com/pub/a/oreilly/tim/news/2005/09/30/what-isweb-20.html, 2005

[4] L. Safko, and D. K. Brake, The Social Media Bible: Tactics, Tools, and Strategies for Business Success. New Jersey: John Wiley \& Sons, Inc., 2009.

[5] D. K. Wright, and M. D. Hinson, "An Updated Look at the Impact of Social Media on Public Relations Practice," Public Relations Journal, Vol. 3, 2009, pp. 1-27.

[6] R. Hoegg, R. Martignoni, M. Meckel, \& K. Stanoevska-Slabeva, "Overview of business models for Web 2.0 communities," Proceedings of GeNeMe 2006 Conference, Dresden, Germany. http://www.alexandria.unisg.ch/Publikationen/31411, 2006.

[7] J. H. Kietzmann, K.Hermkens, I.P.McCarthy, and B.S. Silvestre, "Social media? Get serious! Understanding the functional building blocks of social media," Business Horizons, Vol. 54, 2011, pp. 241-251.

[8] D. Dykeman, "How do you define social media?" http://broadcastingbrain.com/2008/02/09/how-do-you-define-social-media/, 2008.

[9] J. Strauss, and R. Frost, E-Marketing, 5/E. New Jersey: Prentice Hall, 2009.

[10] W. Nasri, and L. Charfeddine, "An Exploration of Facebook.Com Adoption in Tunisia Using Technology Acceptance Model (TAM) and Theory of Reasoned Action (TRA)," Interdisciplinary Journal Of Contemporary Research In Business, Vol. 4, 2012, pp. 948-968.

[11] J. Raacke, and J. Bonds-Raacke, "MySpace and Facebook: Applying the Uses and Gratifications Theory to Exploring Friend-Networking Sites," Cyberpsychology \& Behavior, Vol. 11, 2008, pp. 169-174.

[12] M.S. Md..Rahman, M.Haque, and M. B. K. Khan, "The Influence of Privacy, Trust towards Online Social Network: An Exploratory Study on Bangladeshi Customers Perception," European Journal of Economics, Finance and Administrative Sciences, Vol. 35, 2011, pp. 126-134.

[13] C. Steinfield, N. Ellison, \& C. Lampe, "Social capital, self-esteem, and use of online social network sites: A longitudinal analysis," Journal of Applied Developmental Psychology, Vol. 29, 2008, pp. 434-445.

[14] D.S.P. Cermak, K.M. File, \& R, A. Prince, "Customer Participation in Service Specification and Delivery," Journal of Applied Business Research, Vol. 10, 1994, pp. 90-97.

[15] A.R. Rodi, \& S.S. Kleine, Customer Participation in Service Production and Delivery. Handbook of Services Marketing and Management, California: Sage Publications, Inc., 2000.

[16] P.A. Dabholkar, "Customer Evaluations of New Technology-Based SelfService Options: An Investigation of Alternative Models of Service Quality," International Journal of Research in Marketing, Vol. 13, 1996, pp. 29-51.

[17] J.W. Palmer, "Web Site Usability, Design, and Performance Metrics," Information Systems Research, Vol. 13, 2002, pp. 151-167. 